\title{
Bioactive $\mathrm{M}$ (II) complexes of amino acid-based $\mathrm{N}_{3} \mathrm{O}$ donor mixed ligand: in vitro and in silico DNA binding studies
}

\author{
T. Daniel Prakash ${ }^{1} \cdot$ V. Violet Dhayabaran ${ }^{1}$
}

Received: 27 September 2016 / Accepted: 19 April 2017 / Published online: 5 May 2017

(C) Springer-Verlag Berlin Heidelberg 2017

\begin{abstract}
Three novel mixed ligand $\mathrm{M}(\mathrm{II})$ complexes, namely $\left[\mathrm{CoL}^{1} \mathrm{~L}^{2} \mathrm{Cl}_{2}\right](1),\left[\mathrm{CuL}^{1} \mathrm{~L}^{2} \mathrm{Cl}_{2}\right](2)$, and $\left[\mathrm{ZnL}^{1} \mathrm{~L}^{2} \mathrm{Cl}_{2}\right]$ (3), were synthesized using 1,4-naphthoquinone, L-histidine, and 1,10-phenanthroline as ligands. The ligand framework and the corresponding structural changes on complexation were ascertained based on the results of elemental analysis, conductivity measurements, magnetic behavior, FT-IR, UV-visible, ${ }^{1} \mathrm{H}$ NMR, ${ }^{13} \mathrm{C}$ NMR, ESR spectral studies, and ESI mass spectrometry. The biological action of the ligand $(L)$ and complexes $1-3$ such as DNA binding and cleaving ability were studied. Results suggest that the ligand and the complexes could interact with calf thymus-DNA (CT-DNA) via intercalation mode. Additionally, complex 2 displayed potential antioxidant activity in in vitro studies. Docking simulation was performed to position the ligand and the complexes into the active site of BDNA (IBNA) to determine the probable binding mode.
\end{abstract}

Keywords Mixed ligand complexes $\cdot$ DNA binding $\cdot$ DNA cleavage $\cdot$ Antioxidant activity $\cdot$ Molecular docking

\section{Introduction}

The design and synthesis of mixed ligand coordination complexes of transition metals has been receiving significant

Electronic supplementary material The online version of this article (doi:10.1007/s12154-017-0170-3) contains supplementary material, which is available to authorized users.

V. Violet Dhayabaran

violetstaff@yahoo.co.in

1 PG and Research Department of Chemistry, Bishop Heber College (Autonomous), Tiruchirappalli, Tamilnadu 620017, India interest for their bioinorganic relevance as well as for their wide range of physicochemical properties which includes unusual magnetic properties and catalytic activities $[1,2]$. Chemically mixed donor ligands are significant because of their versality, flexibility, and ability to coordinate with several metal ions [3]. Quinones, particularly 1,4-naphthoquinones, have attracted continuing interest over the years for their fungicidal, antibacterial, and anticancer activities [4]. The biological activity of quinones results from their ability to accept one or two electrons to form the corresponding radical anion or dianion species, and their acid-base properties [5].

Amino acids are the building blocks of proteins and take part in all major processes in organisms [6]. Histidine occupies importance as a ligand in many metallo-enzymatic reactions [7]. Due to the presence of an imidazole ring, the molecule possesses three extra potential sites for (de)protonation and metal binding in addition to the two $\left(\mathrm{NH}_{2}\right.$ and $\left.\mathrm{COOH}\right)$ amino acid end groups [8]. The incorporation of the amino functional group at the 2-position of 1,4-naphthoquinone has led to the generation of enhanced biological and physiochemical properties and also the constitution of a molecular framework of several natural products such as rifamycins [9], kinamycins [10], rifampicins [11], and streptovaricins [12].

1,10-phenanthroline is a typical chelating bidentate ligand for transition metal ions that has played a vital role in the development of coordination chemistry and still continues to be of considerable interest as a versatile starting material for organic, inorganic, and supramolecular chemistry [13-15]. Mixed ligand complexes containing phenanthroline have attracted interest over the last decades because of their promising anti-tumor activities in cis-platin-resistant model systems [16]. In continuance of our previous work [17], herein, we report the synthesis, characterization, and spectroscopic study on DNA binding, cleavage, antimicrobial and antioxidant activities of mixed ligand $\mathrm{Co}(\mathrm{II}), \mathrm{Cu}(\mathrm{II})$, and $\mathrm{Zn}$ (II) complexes 
involving 1,4-naphthoquinone, L-histidine, and 1,10phenanthroline ligands. Molecular docking study of the precursor ligand and its metal complexes were also carried out with BDNA.

\section{Experimental methods}

Chemicals like 1,4-naphthoquinone, L-histidine, 1,10phananthroline, and metal chlorides were obtained from Sigma-Aldrich and used as purchased without any further purification. Calf-thymus DNA (CT-DNA) (Himedia, India) and pBR322 plasmid DNA (Bangalore Genei, India) were used for DNA binding and cleavage studies, respectively. All other chemicals and solvents were purchased from E-Merck, India, and were used without further purification.

\section{Instruments employed}

Elemental analysis $(\mathrm{C}, \mathrm{H}, \mathrm{N}$, and $\mathrm{O})$ data was obtained using a Euro Vector elemental analyzer. The molar conductivity of the complexes in DMSO solution $\left(10^{-3} \mathrm{M}\right)$ was measured in a deep vision 601 model digital conductometer at room temperature. Vibration spectra was recorded on a Perkin Elmer Spectrum RX I spectrophotometer using $\mathrm{KBr}$ disks. The NMR spectra of the ligand and zinc complex were recorded on a Bruker AV-III FT NMR $500 \mathrm{MHz}$ spectrometer operating at room temperature (RT). The EPR spectrum was accomplished in liquid $\mathrm{N}_{2}$ temperature $(77 \mathrm{~K})$ using tetracyanoethylene (TCNE) as the g-marker in a JES-FA200 ESR spectrometer. Molecular weights of the complexes were determined using the JEOL GCMATE II GC-MS spectrometer. Perkin Elmer Lambda 35 UV-visible spectrophotometer was employed to achieve the electronic spectra. Cyclic voltammetric (CV) experiments were recorded on a Princeton Applied Research electrochemical analyzer. CD measurements were recorded on a JASCO (J-810) spectropolarimeter.

\section{Synthesis of ligand (L)}

For the synthesis of ligand (L), an ethanolic solution $(5 \mathrm{~mL})$ of 1,4-naphthoquinone $(0.158 \mathrm{~g}, 0.1 \mathrm{M})$ was added to an ethanolic solution $(7 \mathrm{~mL})$ of L-histidine $(0.155 \mathrm{~g}, 0.1 \mathrm{M})$. The resultant mixture was stirred for $45 \mathrm{~min}$ and refluxed at $60{ }^{\circ} \mathrm{C}$ for $6 \mathrm{~h}$. The solid product formed was filtered, washed, recrystallized using ethanol, and dried in vacuum. Yield, $68 \%$. Color, greenish yellow. M.p,. $165{ }^{\circ} \mathrm{C}$. ESI-MS, $\mathrm{m} / \mathrm{z}=311.09\left[\mathrm{C}_{16} \mathrm{H}_{13} \mathrm{~N}_{3} \mathrm{O}_{4}\right]$. Anal. Calc. for $\mathrm{C}_{16} \mathrm{H}_{13} \mathrm{~N}_{3} \mathrm{O}_{4}, \mathrm{C}, 61.73 ; \mathrm{H}, 4.21 ; \mathrm{N}$, 13.50; O, 20.56. Found, C, 61.71; H, 4.20; N, 13.48; O, $20.55(\%)$. FT-IR $\left(v, \mathrm{~cm}^{-1}\right), 3759 v(-\mathrm{NH}), 1457 v_{\text {asy }}\left(\mathrm{COO}^{-}\right)$, $1339 v_{\mathrm{sy}}\left(\mathrm{COO}^{-}\right), 1795 \vee(\mathrm{C}=\mathrm{O}) .{ }^{1} \mathrm{H}$ NMR [DMSO-d ${ }_{6}$, ppm], $\delta 9.74\left(\mathrm{~s}, 1 \mathrm{H}, \mathrm{NH}_{\text {imidazole }}\right), 9.73(\mathrm{~s}, 1 \mathrm{H}, \mathrm{OH}), 8.6(\mathrm{~s}$, $1 \mathrm{H}, \mathrm{NH}), 8.63\left(\mathrm{~s}, 1 \mathrm{H}, J 7.8 \mathrm{~Hz}, \mathrm{CH}_{\text {imidazole }}\right), 7.86(\mathrm{~d}, 2 \mathrm{H}, J$ $7.6 \mathrm{~Hz}, \mathrm{Ar}-\mathrm{H}), 7.83$ (d, 2H, J 7.6 Hz, Ar-H), $3.18 \mathrm{ppm}$ (s, 1H, $J$ $\left.3.85 \mathrm{~Hz}, \mathrm{CH}_{\text {dione }}\right){ }^{13} \mathrm{C}$ NMR [DMSO-d 6 , ppm], $\delta 190\left(\mathrm{C}_{\text {dione }}\right)$, $161\left(\mathrm{C}_{\text {carboxylic acid }}\right), 158.5$ ( $\left.\mathrm{C}_{\text {amine }}\right), 135-125\left(\mathrm{C}_{\text {aromatic }}\right), 140$, $122,119\left(\mathrm{C}_{\text {imidazole }}\right), 93 \mathrm{ppm}\left(\mathrm{C}_{\text {chiral }}\right) . \mathrm{UV}-\mathrm{Vis}(\mathrm{DMSO}, \mathrm{rt})[\lambda$ $(\mathrm{nm})], 259\left(\pi \rightarrow \pi^{*}\right), 380\left(\mathrm{n} \rightarrow \pi^{*}\right)$.

\section{Synthesis of complexes 1-3}

For the synthesis of mixed ligand complexes, initially, an equimolar ethanolic mixture $(10 \mathrm{~mL})$ of the ligand $(0.311 \mathrm{~g}$, $0.1 \mathrm{M})$ and the metal chloride salt $\left(\mathrm{CoCl}_{2} \cdot 6 \mathrm{H}_{2} \mathrm{O}-0.237 \mathrm{~g}\right.$ $(0.1 \mathrm{M}), \mathrm{CuCl}_{2} .2 \mathrm{H}_{2} \mathrm{O}-0.170 \mathrm{~g}(0.1 \mathrm{M}), \mathrm{ZnCl}_{2}-0.136 \mathrm{~g}$ $(0.1 \mathrm{M}))$ was refluxed at $70{ }^{\circ} \mathrm{C}$ under constant stirring for $1 \mathrm{~h}$. Then, 1,10-phenanthroline $(0.180 \mathrm{~g}, 0.1 \mathrm{M})$ in ethanol $(5 \mathrm{ml})$ was added to the above reaction mixture and allowed to reflux at $67{ }^{\circ} \mathrm{C}$ for $2 \mathrm{~h}$. The resultant product was filtered, washed with ethanol, and then recrystallized using ether. The solid product was dried in vacuum and kept in a desiccator.

\section{Complex $1\left[\mathrm{CoL}^{1} \mathrm{~L}^{2} \mathrm{Cl}_{2}\right]$}

Yield, 70\%. Color, brown. M.p., $242{ }^{\circ} \mathrm{C}$. ESI-MS, $\mathrm{m} / \mathrm{z}=620.03\left[\mathrm{C}_{28} \mathrm{H}_{21} \mathrm{Cl}_{2} \mathrm{CoN}_{5} \mathrm{O}_{4}\right]$. Anal. Calc. for $\mathrm{C}_{28} \mathrm{H}_{21} \mathrm{Cl}_{2} \mathrm{CoN}_{5} \mathrm{O}_{4}, \mathrm{C}, 54.13 ; \mathrm{H}, 3.41 ; \mathrm{N}, 11.27 ; \mathrm{O}, 10.30$. Found, C, 54.11; H, 3.39; N, 11.26; O $10.28(\%)$. FT-IR ( $($, $\left.\mathrm{cm}^{-1}\right), 3403 v(-\mathrm{NH}), 1455 v_{\mathrm{asy}}\left(\mathrm{COO}^{-}\right), 1336 v_{\mathrm{sy}}\left(\mathrm{COO}^{-}\right)$, $1639 \vee(\mathrm{C}=\mathrm{O}), 412 \vee(\mathrm{M}-\mathrm{O}), 538 \vee(\mathrm{M}-\mathrm{N})$. UV-Vis (DMSO, rt) $[\lambda(\mathrm{nm})], 274\left(\pi \rightarrow \pi^{*}\right), 342\left(\mathrm{n} \rightarrow \pi^{*}\right), 479$ $(\mathrm{d} \rightarrow \mathrm{d}) . \Lambda_{\mathrm{m}}\left(\Omega^{-1} \mathrm{~cm}^{3} \mathrm{~mol}^{-1}\right)$ 13.12. $\mu_{\text {eff }}$ (BM) 5.09.

\section{Complex $2\left[\mathrm{CuL}^{1} \mathrm{~L}^{2} \mathrm{Cl}_{2}\right]$}

Yield, 69\%. Color, bluish green. M.p., $266{ }^{\circ} \mathrm{C}$. ESI-MS, $\mathrm{m} / \mathrm{z}=624.03\left[\mathrm{C}_{28} \mathrm{H}_{21} \mathrm{Cl}_{2} \mathrm{CuN}_{5} \mathrm{O}_{4}\right]$. Anal. Calc. for $\mathrm{C}_{28} \mathrm{H}_{21} \mathrm{Cl}_{2} \mathrm{CuN}_{5} \mathrm{O}_{4}, \mathrm{C}, 53.73 ; \mathrm{H}, 3.38 ; \mathrm{N}, 11.19 ; \mathrm{O}, 10.22$. Found, C, 53.71; H, 3.35; N, 11.18; O 10.21 (\%). FT-IR $\left(v, \mathrm{~cm}^{-1}\right), 3409 v(-\mathrm{NH}), 1456 v_{\text {asy }}\left(\mathrm{COO}^{-}\right), 1340$ $v_{\mathrm{sy}}\left(\mathrm{COO}^{-}\right), 1611 v(\mathrm{C}=\mathrm{O}), 430 v(\mathrm{M}-\mathrm{O}), 554 v(\mathrm{M}-\mathrm{N})$. UV-Vis (DMSO, rt) $[\lambda(\mathrm{nm})], 265\left(\pi \rightarrow \pi^{*}\right), 543(\mathrm{~L} \rightarrow$ $\mathrm{MCT}), 480(\mathrm{~d} \rightarrow \mathrm{d}) . \Lambda_{\mathrm{m}}\left(\Omega^{-1} \mathrm{~cm}^{3} \mathrm{~mol}^{-1}\right)$ 16.05. $\mu_{\text {eff }}(\mathrm{BM}) 1.84$.

\section{Complex $3\left[\mathrm{ZnL}^{1} \mathrm{~L}^{2} \mathrm{Cl}_{2}\right]$}

Yield, 74\%. Color, pale yellow. M.p., $286{ }^{\circ} \mathrm{C}$. ESI-MS, $\mathrm{m} / \mathrm{z}=625.03 \quad\left[\mathrm{C}_{28} \mathrm{H}_{21} \mathrm{Cl}_{2} \mathrm{~N}_{5} \mathrm{O}_{4} \mathrm{Zn}\right]$. Anal. Calc. for $\mathrm{C}_{28} \mathrm{H}_{21} \mathrm{Cl}_{2} \mathrm{~N}_{5} \mathrm{O}_{4} \mathrm{Zn}, \mathrm{C}, 53.57 ; \mathrm{H}, 3.37 ; \mathrm{N}, 11.16 ; \mathrm{O}$, 10.19. Found, C, 53.55; H, 3.36; N, 11.14; O, 10.18 (\%). FT-IR $\left(v, \mathrm{~cm}^{-1}\right), 3411 v(-\mathrm{NH}), 1454 v_{\text {asy }}\left(\mathrm{COO}^{-}\right)$, $1335 v_{\mathrm{sy}}\left(\mathrm{COO}^{-}\right), 1634 \vee(\mathrm{C}=\mathrm{O}), 427 v(\mathrm{M}-\mathrm{O}), 533$ 
$v(\mathrm{M}-\mathrm{N}) .{ }^{1} \mathrm{H}$ NMR [DMSO-d $\left.6, \mathrm{ppm}\right], \delta 8.76(\mathrm{~s}, 1 \mathrm{H}$, $\left.\mathrm{NH}_{\text {imidazole }}\right), 8.74(\mathrm{~s}, 1 \mathrm{H}, \mathrm{OH}), 8.54(\mathrm{~s}, 1 \mathrm{H}, J 7.73 \mathrm{~Hz}$, $\mathrm{CH}_{\text {imidazole }}$ ), 8.13-7.47 (m, 12H, Ar-H), $6.6 \mathrm{ppm}$ (s, 1H, J $\left.3.37 \mathrm{~Hz}, \mathrm{CH}_{\text {dione }}\right) .{ }^{13} \mathrm{C}$ NMR [DMSO-d $6, \mathrm{ppm}$ ], $\delta 194$ $\left(\mathrm{C}_{\text {dione }}\right), 170\left(\mathrm{C}_{\text {carboxylic acid }}\right), 158.4\left(\mathrm{C}_{\text {amine }}\right), 144-126$ $\left(\mathrm{C}_{\text {aromatic }}\right), 140,123,119\left(\mathrm{C}_{\text {imidazole }}\right), 51 \mathrm{ppm}\left(\mathrm{C}_{\text {chiral }}\right) . \mathrm{UV}-$ Vis $(\mathrm{DMSO}, \mathrm{rt})[\lambda(\mathrm{nm})], 272\left(\pi \rightarrow \pi^{*}\right), 378\left(\mathrm{n} \rightarrow \pi^{*}\right) . \Lambda_{\mathrm{m}}$ $\left(\Omega^{-1} \mathrm{~cm}^{3} \mathrm{~mol}^{-1}\right)$ 10.45. $\mu_{\text {eff }}(\mathrm{BM})$ diamagnetic.

\section{Biological studies}

The procedure for DNA binding, cleavage, antioxidant and antimicrobial activities, and molecular docking studies is given in the Supplementary file S1.

\section{Results and discussion}

The synthetic route of complexes $1-3$ of mixed ligands derived from L-histidine, 1,4-naphthoquinone, and 1,10phenanthroline is represented in Fig. 1. The significant properties of the synthesized ligand and its metal complexes such as yield, color, elemental analysis, magnetic moment, and molar conductance were examined.

\section{Physical and chemical properties}

All the compounds are stable for extended periods and the complexes are remarkably soluble in DMSO and DMF. The results of elemental analysis of all the synthesized compounds are in good agreement with the calculated values. This proves that the stoichiometry of the complexes is $\left[\mathrm{ML}^{1} \mathrm{~L}^{2} \mathrm{Cl}_{2}\right]$ wherein both the ligands acts as a bidentate donor.

\section{Molar conductivity}

Molar conductance values of complexes $1-3$ in DMSO $\left(1 \times 10^{-3} \mathrm{M}\right)$ at $25^{\circ} \mathrm{C}$ suggest their non-electrolytic nature (10.45-16.05 $\left.\Omega^{-1} \mathrm{~cm}^{2} \mathrm{~mol}^{-1}\right)$. The absence of chloride (counter) ion is confirmed from the Volhard's test. It also indicates that the chloride anions bind to the metal ions as ligands and do not ionize further.

\section{FT-IR spectroscopy}

The IR spectra of the ligand and the complexes provided significant information about the metal ligand bonding. The typical infrared spectrum of the ligand $(L)$ and its $\mathrm{M}(\mathrm{II})$ complexes were represented in Fig. S2. The spectra of the ligand displayed characteristic absorption band at $3759 \mathrm{~cm}^{-1}$ corresponding to $v(-\mathrm{NH})$, which confirms the formation of the ligand from 1,4-naphthoquinone and L-histidine [18]. In addition, the ligand also shows peaks at 1457, 1339, and $1795 \mathrm{~cm}^{-1}$ which can be attributed to $v_{\text {asy }}\left(\mathrm{COO}^{-}\right)$, $v_{\text {sy }}\left(\mathrm{COO}^{-}\right)$, and $v(\mathrm{C}=\mathrm{O})$, respectively. In metal complexes, the bands due to $v(-\mathrm{NH})$ and $v(\mathrm{C}=\mathrm{O})$ were shifted to lower wave numbers in the range of $3403-3410 \mathrm{~cm}^{-1}$ and 1613-1637 $\mathrm{cm}^{-1}$, respectively. This indicates that deprotonation had taken place prior to coordination of the nitrogen and carbonyl oxygen to the metal ion [19, 20]. This observation is further supported by $\mathrm{M}-\mathrm{N}$ and $\mathrm{M}-\mathrm{O}$ characteristic bands noted at 533-554 and $412-430 \mathrm{~cm}^{-1}$, respectively, in all the complexes. The bands due to $v_{\text {asy }}\left(\mathrm{COO}^{-}\right), v_{\text {sy }}\left(\mathrm{COO}^{-}\right)$, and $v(\mathrm{C}=\mathrm{O})$ remain unaltered, which authorizes their non-involvement in coordination with metal ion. In addition, the bands attributed to the azomethine $v(\mathrm{C}=\mathrm{N})$ stretching of 1,10-phenanthroline were shifted to
Fig. 1 Synthetic route for the preparation of the ligand $(L)$ and complexes 1-3

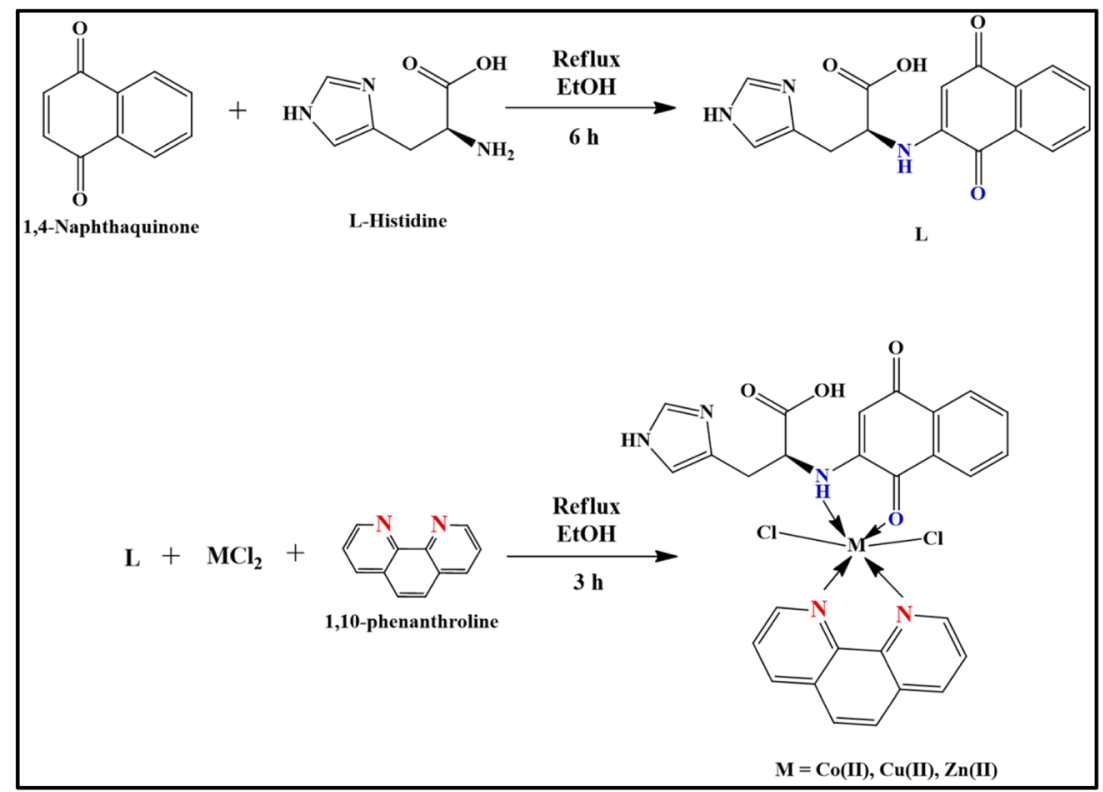


lower frequencies $\left(1589-1559 \mathrm{~cm}^{-1}\right)$ in the metal complexes, signifying the coordination of 1,10-phenanthroline to metal through the azomethine $[21,22]$. From the above discussion, the formation of the ligand $(L)$ and its metal complexes is confirmed.

\section{Absorption spectroscopy and magnetic moment}

The electronic absorption spectra of the ligand (L) and its metal complexes recorded in DMSO solution in the region 200-800 nm are depicted in Fig. S3. In the UV spectrum of ligand (L), notably two characteristic absorption bands are observed. A weak absorption band at $259 \mathrm{~nm}$, due to the $\pi \rightarrow \pi^{*}$ transition of $\pi$ electrons present in the aromatic phenyl ring $(\mathrm{C}=\mathrm{C})$ and the imine group $(-\mathrm{C}=\mathrm{N})$ in the imidazole ring. The strong absorption band at $380 \mathrm{~nm}$ is allocated to $\mathrm{n} \rightarrow \pi^{*}$ transition of non-bonded electrons available in -C-N groups.

Similarly, the absorption spectra of the complexes also show the characteristic $\pi \rightarrow \pi^{*}$ and $\mathrm{n} \rightarrow \pi^{*}$ bands, but they are slightly shifted in their positions, which may be due to the coordination of the ligand to metal ion. The absorption spectrum of the Co(II) complex exhibit two absorption bands at 274 and $342 \mathrm{~nm}$ corresponding to the transitions $\pi \rightarrow \pi^{*}$ and $n \rightarrow \pi^{*}$, respectively. In addition, the spectrum also displays a new band at $479 \mathrm{~nm}$, which can be assigned to characteristic $\mathrm{d} \rightarrow \mathrm{d}$ transition. These bands are characteristic of high spin octahedral $\mathrm{Co}$ (II) complexes [23]. The magnetic moment value of the $\mathrm{Co}$ (II) complex is $5.09 \mathrm{BM}$. In the case of the $\mathrm{Cu}(\mathrm{II})$ complex, it exhibits two prominent bands at 274 and $344 \mathrm{~nm}$ are assignable to $\pi \rightarrow \pi^{*}$ and $\mathrm{n} \rightarrow \pi^{*}$ transition. The d-d transition band of the $\mathrm{Cu}(\mathrm{II})$ complex was observed at $480 \mathrm{~nm}$ corresponding to ${ }^{2} \mathrm{~B}_{1 \mathrm{~g}} \rightarrow{ }^{2} \mathrm{E}_{1 \mathrm{~g}}$ transition. These values are consistent with the octahedral environment around the $\mathrm{Cu}$ (II) ion [24]. The magnetic moment value of $1.84 \mathrm{BM}$ for the same complex further confirms six coordinate octahedral geometry. For the $\mathrm{Zn}$ (II) complex, the bands due to $\pi \rightarrow \pi^{*}$ and $\mathrm{n} \rightarrow \pi^{*}$ transitions appeared at 272 and $378 \mathrm{~nm}$. It is obvious that the $\mathrm{d} \rightarrow \mathrm{d}$ transition for the zinc complex is forbidden as it is possessing $\mathrm{d}^{10}$ configuration. The geometry of all the complexes was further confirmed by the observed magnetic moment values.

\section{${ }^{1} \mathrm{H}$ and ${ }^{13} \mathrm{C} N \mathrm{NM}$ spectroscopy}

The formation of the ligand and its metal complexes was further confirmed by ${ }^{1} \mathrm{H}$ and ${ }^{13} \mathrm{C}$ NMR spectra in DMSO- $\mathrm{d}_{6}$ solution using TMS as standard (Fig. S4). As can be seen from the Fig. S4, the spectra of the ligand show a singlet peak at $\delta 8.6 \mathrm{ppm}$ integrates for the -NH group. Furthermore, a sharp singlet peak for the ortho-position of naphthoquinone appeared at $\delta 3.18 \mathrm{ppm}$. It is also to be noted that no peak was observed for the meta-position of naphthoquinone. This supports the formation of the ligand. The spectra of the ligand also display a set of peaks. The characteristic peak for imidazolium amine was observed at $\delta$ $9.74 \mathrm{ppm}$. While the peaks due to carboxylic acid and $\mathrm{C} 2-\mathrm{H}$ of imidazole was observed at $\delta 9.73$ and $8.63 \mathrm{ppm}$, respectively. On complexation with metal ion, the peak due to -NH disappeared. On the other hand, the peaks due to the ortho-position of naphthoquinone were shifted upwards in the metal complex $(\delta 6.6 \mathrm{ppm})$. This confirms that the ligand is in coordination with metal ion through nitrogen of the $-\mathrm{NH}$ group. On comparison with the ${ }^{1} \mathrm{H}$ NMR spectrum of ligand $(L)$, the peaks corresponding to imidazolium amine, carboxylic acid, and $\mathrm{C} 2-\mathrm{H}$ of imidazole was slightly shifted downwards $(\delta 8.76,8.74$, and $8.54 \mathrm{ppm})$ due to the presence of a metallic center. This reveals their non-involvement in coordination.

The ${ }^{13} \mathrm{C}$ NMR spectra (Fig. S5) was also in agreement with the proposed structures. The ligand exhibits a signal at $\delta 158.5 \mathrm{ppm}$ corresponding to amine substituted to the meta-position of naphthoquinone carbon nuclei $(=\mathrm{C}-\mathrm{N})$. It also displays signal at $\delta 190 \mathrm{ppm}$ could be attributed to the quinone carbonyl group. In the $\left[\mathrm{ZnL}^{1} \mathrm{~L}^{2} \mathrm{Cl}_{2}\right]$ complex, the peak due to amine at the meta-position of naphthoquinone was slightly varied $(\delta 158.4 \mathrm{ppm})$. In addition, the characteristic resonance peak for quinone carbonyl was shifted upwards $(\delta 194 \mathrm{ppm})$. This clearly indicates the coordination of the quinone carbonyl group $(\mathrm{C}=\mathrm{O})$ with the metal center. The peaks due to other groups remain unchanged, which confirms their non-involvement in coordination.

\section{Mass spectrometry}

The formation of the ligand and metal complexes and the speciation of various ionic forms in DMSO solution were studied with ESI-MS. The spectra of the ligand $(L)$ (Fig. S6) displayed a prominent peak at $\mathrm{m} / \mathrm{z}, 311$ corresponding to the $\left[\mathrm{C}_{16} \mathrm{H}_{13} \mathrm{~N}_{3} \mathrm{O}_{4}\right]^{+}$ion, which is in good agreement with its formula weight. The spectra also shows a series of peaks at $\mathrm{m} / \mathrm{z} 267,225,211,189,167$, $121,109,95$, and 56 corresponding to $\left[\mathrm{C}_{15} \mathrm{H}_{13} \mathrm{~N}_{3} \mathrm{O}_{2}\right]^{+}$, $\left[\mathrm{C}_{14} \mathrm{H}_{11} \mathrm{NO}_{2}\right]^{+},\left[\mathrm{C}_{14} \mathrm{H}_{13} \mathrm{NO}\right]^{+},\left[\mathrm{C}_{12} \mathrm{H}_{15} \mathrm{NO}\right]^{+}$, $\left[\mathrm{C}_{10} \mathrm{H}_{17} \mathrm{NO}\right]^{+},\left[\mathrm{C}_{8} \mathrm{H}_{9} \mathrm{O}\right]^{+},\left[\mathrm{C}_{7} \mathrm{H}_{9} \mathrm{O}\right]^{+},\left[\mathrm{C}_{6} \mathrm{H}_{6} \mathrm{O}\right]^{+}$, and $\left[\mathrm{C}_{3} \mathrm{H}_{4} \mathrm{O}\right]^{+}$ions, respectively.

Furthermore, Fig. S7 represents the mass spectra of the $\left[\mathrm{CoL}^{1} \mathrm{~L}^{2} \mathrm{Cl}_{2}\right]$ complex. The mass spectra of the $\mathrm{Co}$ (II) complex exhibits the molecular ion peak at $\mathrm{m} / \mathrm{z}$ 620.03, which coincides with its formula weight. Also, the spectrum displays the fragments at $m / z, 543,502,454,366,308,269,213,169$, 148,96 , and 69 corresponding to $\left[\mathrm{C}_{27} \mathrm{H}_{23} \mathrm{ClCoN}_{5} \mathrm{O}_{2}\right]^{+}$, $\left[\mathrm{C}_{26} \mathrm{H}_{23} \mathrm{ClCoN}_{3} \mathrm{O}_{2}\right]^{+},\left[\mathrm{C}_{25} \mathrm{H}_{21} \mathrm{CoN}_{3} \mathrm{O}_{2}\right]^{+},\left[\mathrm{C}_{18} \mathrm{H}_{17} \mathrm{CoN}_{3} \mathrm{O}_{2}\right]^{+}$, $\left[\mathrm{C}_{16} \mathrm{H}_{13} \mathrm{CoN}_{2} \mathrm{O}\right]^{+},\left[\mathrm{C}_{12} \mathrm{H}_{22} \mathrm{CoN}_{2} \mathrm{O}\right]^{+},\left[\mathrm{C}_{8} \mathrm{H}_{14} \mathrm{CoN}_{2} \mathrm{O}\right]^{+}$, 
Table 1 Electronic absorption spectral properties of the ligand $(L)$ and complexes $1-3$ with CT-DNA

\begin{tabular}{|c|c|c|c|c|}
\hline \multirow[t]{2}{*}{ Compound } & \multicolumn{2}{|c|}{$\lambda_{\max }(\mathrm{nm})$} & \multirow[t]{2}{*}{$\Delta \lambda(\mathrm{nm})$} & \multirow[t]{2}{*}{$K_{\mathrm{b}}\left(\mathrm{M}^{-1}\right) \times 10^{5}$} \\
\hline & Free & Bound & & \\
\hline$[\mathrm{L}]$ & 276.98 & 274.85 & 2.13 & $2.59 \pm 0.09$ \\
\hline$\left[\mathrm{CoL}^{1} \mathrm{~L}^{2} \mathrm{Cl}_{2}\right]$ & 274.81 & 272.41 & 2.4 & $2.64 \pm 0.12$ \\
\hline$\left[\mathrm{CuL}^{1} \mathrm{~L}^{2} \mathrm{Cl}_{2}\right]$ & 278.25 & 272.67 & 5.58 & $3.11 \pm 0.15$ \\
\hline$\left[\mathrm{ZnL}^{1} \mathrm{~L}^{2} \mathrm{Cl}_{2}\right]$ & 276.97 & 275.49 & 1.48 & $2.41 \pm 0.07$ \\
\hline
\end{tabular}

$\left[\mathrm{C}_{7} \mathrm{H}_{12} \mathrm{CoN}\right]^{+},\left[\mathrm{C}_{5} \mathrm{H}_{11} \mathrm{CoN}\right]^{+}$, and $\left[\mathrm{C}_{3} \mathrm{H}_{5} \mathrm{Co}\right]^{+}$ions, respectively. Similarly, the mass spectra of $\left[\mathrm{CuL}^{1} \mathrm{~L}^{2} \mathrm{Cl}_{2}\right]$ (Fig. S8) and $\left[\mathrm{CoL}^{1} \mathrm{~L}^{2} \mathrm{Cl}_{2}\right]$ (Fig. S9) complexes show the molecular ion peaks at $m / z 624.03$ and 625.03 , respectively, which is in good agreement with their formula weight. The spectra also contain several peaks which can be attributed to their further fragments. The mass spectra of the ligand and its complexes are in good agreement with the structure suggested by elemental analysis, magnetic, and spectral studies.
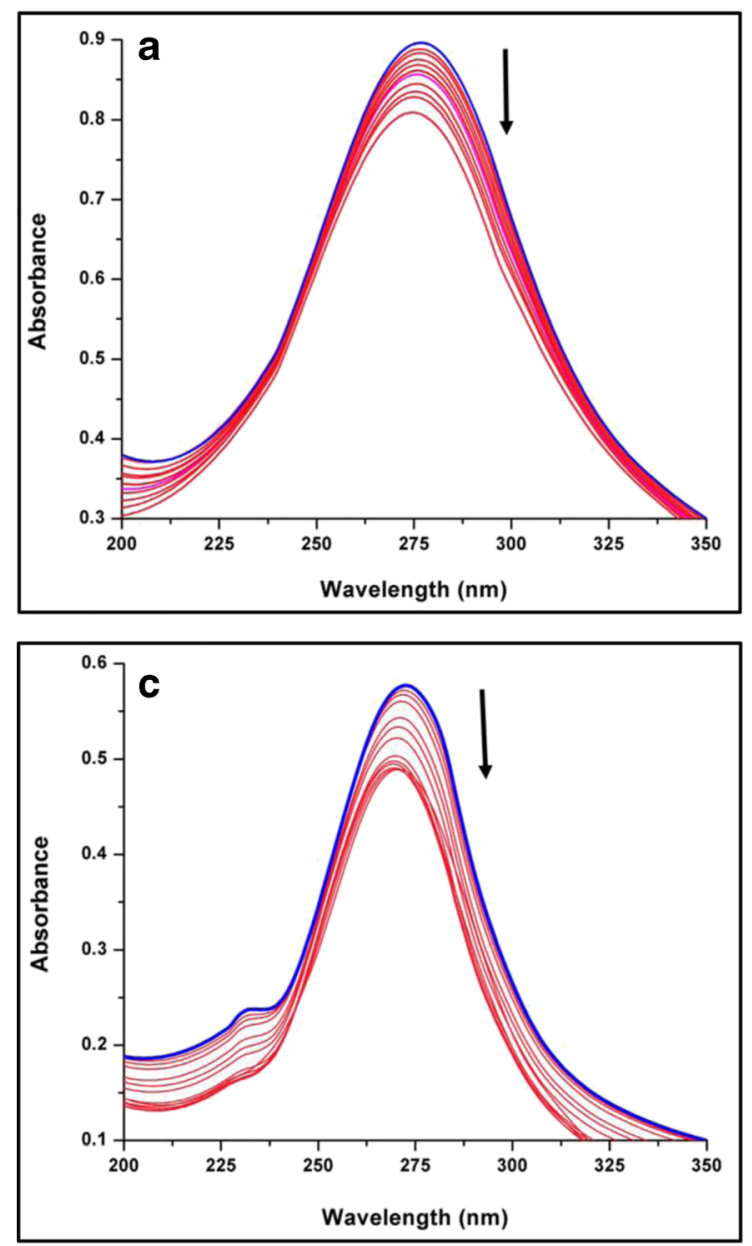

\section{ESR spectroscopy}

The X-band EPR spectra of the $\left[\mathrm{CuL}^{1} \mathrm{~L}^{2} \mathrm{Cl}_{2}\right]$ complex was recorded at liquid nitrogen temperature $(100 \mathrm{~K})$ under the magnetic field strength of $3000 \pm 1000 \mathrm{G}$ with tetracyanoethylene (TCNE) as a field marker (2.0027) and illustrated in Fig. S10. The spectra consisted of a broad axial symmetrical signal with $g_{\amalg}=2.18, g_{\perp}=2.03$ and $g_{\text {avg }}=2.08$ computed from the formula $g_{\mathrm{av}}=1 / 3\left(g_{\amalg}+2 g_{\perp}\right)$. The trend $g_{\amalg}>g_{\perp}>g_{\mathrm{e}}$ (2.0023) further confirmed that the ground state of the $\mathrm{Cu}$ (II) is predominantly $\mathrm{dx}^{2}-\mathrm{y}^{2}$ orbital [25]. These parameters are consistent with the octahedral geometry of the $\mathrm{Cu}$ (II) complexes. According to Hathaway [26], if $\mathrm{G}>4.0$, exchange interaction is negligible while if $\mathrm{G}<4.0$, exchange interaction is considerable and the local tetragonal axes are misaligned. The observed values of exchange interaction for $\left[\mathrm{CuL}^{1} \mathrm{~L}^{2} \mathrm{Cl}_{2}\right]$ complex were found to be 4.97 , indicating negligible exchange interaction.

Based on all the above studies, it is clear that all the complexes possess octahedral geometry with a $\mathrm{N}_{3} \mathrm{O}$ environment around the central metal ion.
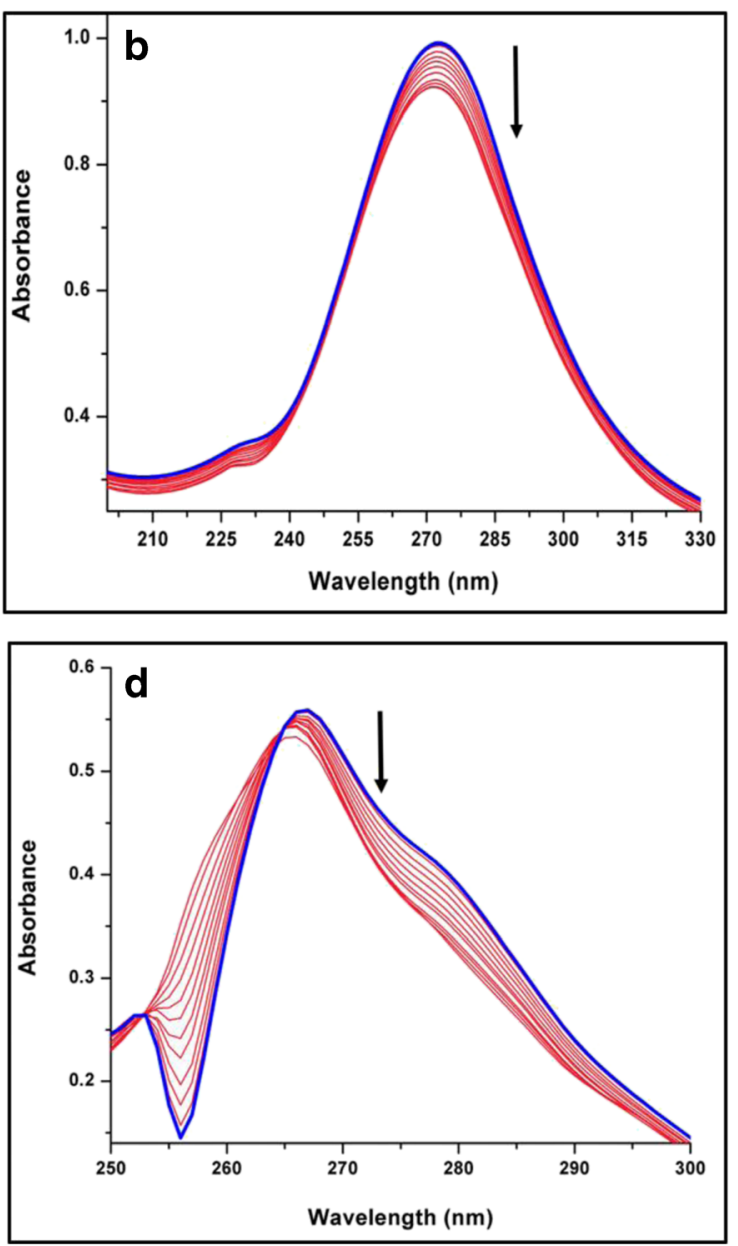

Fig. 2 Electronic absorption spectra of a $L$, b complex 1, c complex 2, and $\mathbf{d}$ complex 3 upon addition of CT-DNA, the arrow shows the absorbance changes upon increasing amounts of CT-DNA 


\section{Binding studies with CT-DNA}

DNA is recognized as the primary target of many metalbased anticancer drugs which exert their drug effects through binding to DNA. Therefore, binding studies reveal the effectiveness of the drug. Metal complexes can bind to DNA through either covalent bonding and/or through non-covalent interactions, such as intercalative, electrostatic, or groove binding of complexes to the DNA helix along major or minor grooves [27]. Having that in mind, the binding studies of the synthesized ligand (L) and its $\mathrm{M}(\mathrm{II})$ complexes were carried out with CTDNA using various techniques.

\section{Absorption spectroscopy}

Electronic absorption spectroscopy is one of the most convenient tools to examine the binding mode and binding extent of metal complexes with DNA [28]. The absorption titrations were performed at a fixed complex concentration, to which the DNA stock solution was gradually added up. The absorption bands were observed at 276.98, 274.81, 278.25, and $276.97 \mathrm{~nm}$ in the absorption spectra of ligand $(L)$, complexes 1, 2, and 3, respectively (Table 1). As seen in Fig. 2, incremental addition of DNA causes a hypochromism with a significant red shift of $1.48-5.58 \mathrm{~nm}$. This shift was attributed to a strong stacking interaction between the aromatic chromophore of the complex and the adjacent base pairs of DNA [29]. The extent of hypochromism gives a measure of the strength of the intercalative binding. The intrinsic binding constants $K_{\mathrm{b}}$ were determined using the Wolfe-Shimer equation [30] by monitoring the changes in absorbance of the $\pi-\pi^{*}$ bands with increasing concentration of CT-DNA:

$\frac{[\mathrm{DNA}]}{\left(\varepsilon_{a}-\varepsilon_{f}\right)}=\frac{[\mathrm{DNA}]}{\left(\varepsilon_{a}-\varepsilon_{f}\right)}+\frac{1}{K_{\mathrm{b}}\left(\varepsilon_{b}-\varepsilon_{f}\right)}$

where [DNA] is the concentration of DNA in base pairs; the apparent extinction coefficients $\varepsilon_{\mathrm{a}}, \varepsilon_{\mathrm{f}}$, and $\varepsilon_{\mathrm{b}}$ correspond to the $A_{\text {obs }} /[$ complex $]$, the extinction coefficient for the free complex, and the extinction coefficient for the complex in fully bound form, respectively. The data were fitted to the above
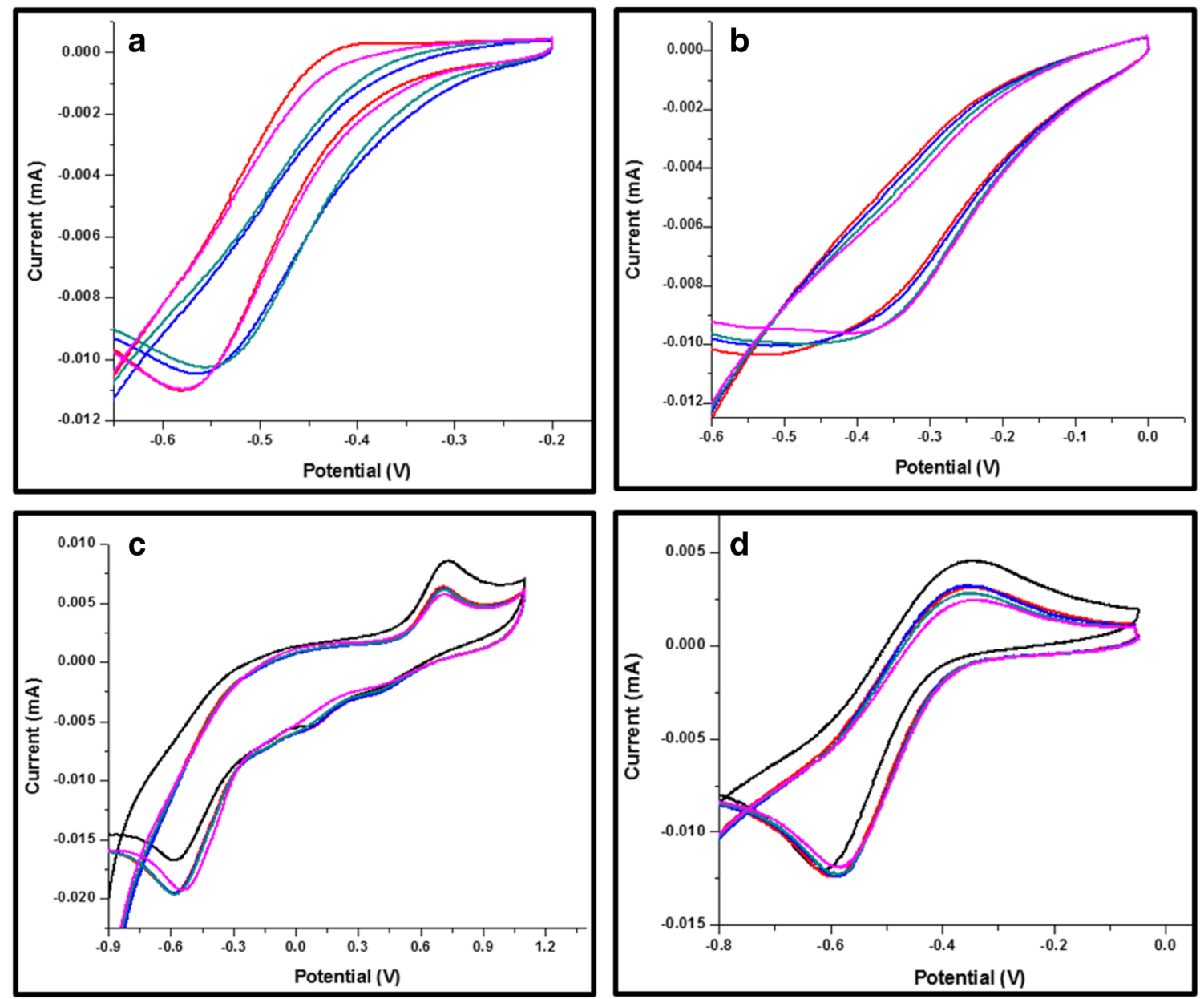

Fig. 3 Cyclic voltammogram of $\mathbf{a} L, \mathbf{b}$ complex 1, c complex 2, and $\mathbf{d}$ complex 3 in buffer $(\mathrm{pH} 7.2)$ at $25^{\circ} \mathrm{C}$ in the presence of increasing concentration of CT-DNA 
equation and $K_{\mathrm{b}}$ was calculated through a plot of [DNA]/ $\left(\varepsilon_{\mathrm{b}}-\varepsilon_{\mathrm{f}}\right)$ versus [DNA]. The obtained $K_{\mathrm{b}}$ values were found to be $2.59 \times 10^{5} \mathrm{M}^{-1}( \pm 0.09), 2.64 \times 10^{5} \mathrm{M}^{-1}( \pm 0.12)$, $3.11 \times 10^{5} \mathrm{M}^{-1}( \pm 0.15)$ and $2.41 \times 10^{5} \mathrm{M}^{-1}( \pm 0.07)$ for ligand $(L)$, complexes 1,2 , and 3 , respectively. These $K_{\mathrm{b}}$ values can be compared to those reported for typical classical intercalator (EB- DNA, $3.3 \times 10^{5} \mathrm{M}^{-1}$ ) [31] and higher than those for related complexes reported earlier $\left(10^{3}-10^{4} \mathrm{M}^{-1}\right)$ [32]. It is the indication of strong intercalation between the studied complexes and the DNA.

\section{Cyclic voltammetry}

To further explore the binding of the complexes with DNA, cyclic voltammetric studies were carried out both in the presence and absence of DNA (Fig. 3). Electrochemical parameters for the interaction of DNA with ligand $(L)$, complexes 1 , 2 , and 3 are shown in Table 2. Upon addition of CT-DNA to the complex, both the anodic and cathodic peak current decreases, signifying that there exist interactions between the complex and DNA [33]. The drop of the voltammetric currents in the presence of CT-DNA may be attributed to slow diffusion of the complexes bound to CT-DNA. The $\mathrm{ip}_{\mathrm{c}} / \mathrm{ip}_{\mathrm{a}}$ ratios of the synthesized ligand and the complexes are 0.512 , $0.868,0.751$, and 0.687 , respectively, which suggests that the reaction of the complex on the glassy carbon electrode surface is a quasi-reversible redox process. After adding CT-DNA to the complex positive shift in potential, a decrease in the current intensity occurs. It is consistent with intercalative binding of the complexes with DNA.

\section{Circular dichroic studies}

The CD spectroscopic technique is applied to monitor the conformational variations of DNA in solution and also as a useful technique for distinguishing the three main DNA binding modes, namely intercalative, outside groove binding, and outside stacking $[34,35]$. The perceived CD spectrum of CTDNA comprises of a positive band at $280 \mathrm{~nm}$ due to base

Table 2 Electrochemical parameters for interaction of the ligand $(L)$ and complexes $1-3$ with CT-DNA

\begin{tabular}{|c|c|c|c|c|c|}
\hline \multirow[t]{2}{*}{ Compound } & \multicolumn{2}{|c|}{$E_{1 / 2}(\mathrm{~V})^{\mathrm{a}}$} & \multicolumn{2}{|c|}{$\Delta E_{\mathrm{p}}(\mathrm{V})^{\mathrm{b}}$} & \multirow[t]{2}{*}{$\mathrm{I} p_{\mathrm{a}} / \mathrm{I} p_{\mathrm{c}}$} \\
\hline & Free & Bound & Free & Bound & \\
\hline$[\mathrm{L}]$ & 0.3315 & 0.4157 & 0.8457 & 0.6127 & 0.512 \\
\hline$\left[\mathrm{CoL}^{1} \mathrm{~L}^{2} \mathrm{Cl}_{2}\right]$ & 1.4872 & 1.5591 & 1.2357 & 1.1643 & 0.868 \\
\hline$\left[\mathrm{CuL}^{1} \mathrm{~L}^{2} \mathrm{Cl}_{2}\right]$ & 0.7253 & 0.8199 & 0.9683 & 0.8752 & 0.751 \\
\hline$\left[\mathrm{ZnL}^{1} \mathrm{~L}^{2} \mathrm{Cl}_{2}\right]$ & 0.2272 & 0.3649 & 0.4317 & 0.3734 & 0.687 \\
\hline
\end{tabular}

${ }^{\mathrm{a}} E_{1 / 2}=\mathrm{Ep}_{\mathrm{a}}+\mathrm{Ep}_{\mathrm{c}} / 2$

${ }^{\mathrm{b}} \Delta E_{\mathrm{p}}=\mathrm{Ep}_{\mathrm{a}}-\mathrm{Ep}_{\mathrm{c}}$

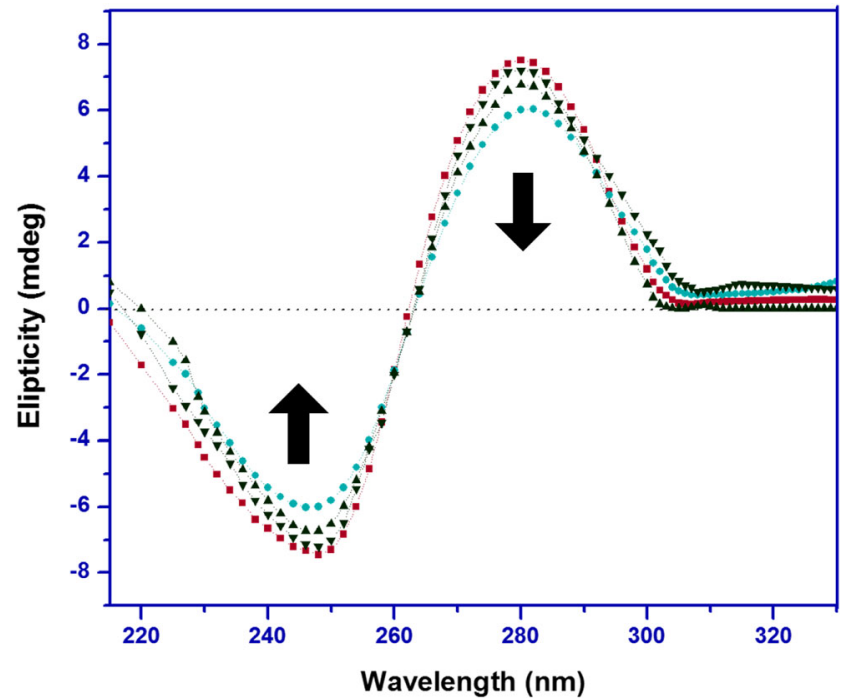

Fig. 4 Circular dichroic spectra of CT-DNA in the presence of complex 2 at different concentrations; [CT-DNA] $=100 \mu \mathrm{M}$. Cell path length $=1 \mathrm{~mm}$. Arrow mark indicates the molar ellipticity change upon increasing complex concentration

stacking and a negative band at $248 \mathrm{~nm}$ due to helicity, which is characteristic of DNA in the right-handed B form. It has been reported that intercalation of a compound to DNA enhances the intensities of both the bands. Figure 4 shows the CD spectra of CT-DNA with the increased concentration of the $\left[\mathrm{CuL}^{1} \mathrm{~L}^{2} \mathrm{Cl}_{2}\right]$ complex. With the addition of the $\mathrm{Cu}(\mathrm{II})$ complex, both the positive $(2 \mathrm{~nm})$ and negative $(3 \mathrm{~nm})$ peaks decreased in intensity accompanied by obvious red shifts. The decreased intensity in the positive and negative bands may be due to the intercalation of the complexes has an effect on the $\pi-\pi$ stacking of DNA base pairs [36]. These observations indicate that the binding mode of the complexes should be intercalative; the stacking of the complex molecules between

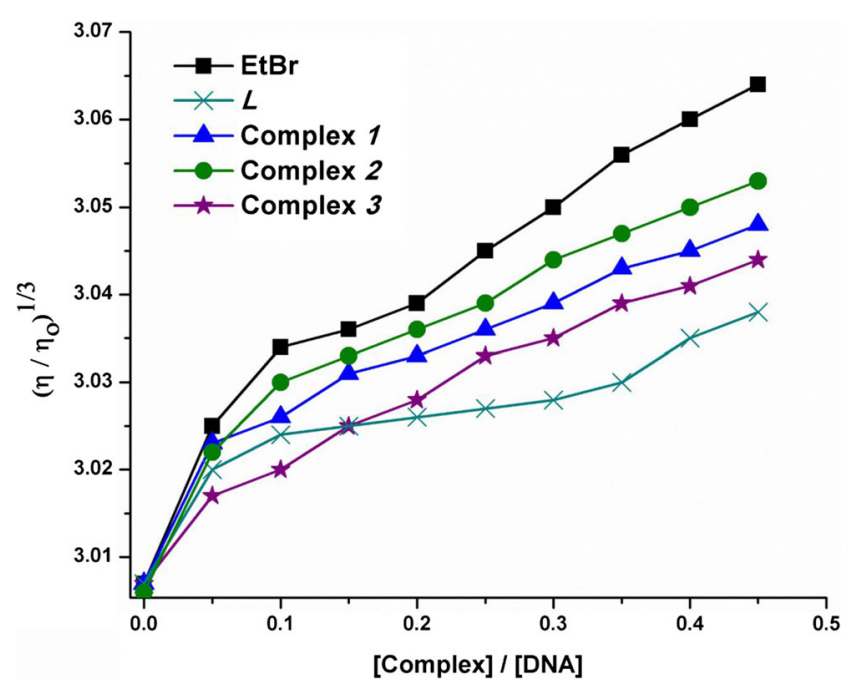

Fig. 5 Effect of increasing concentration of (black square) EB, (multiplication sign) L, (blue triangle) complex 1, (green circle) complex 2, and (star) complex 3 on the relative viscosity of CT-DNA 


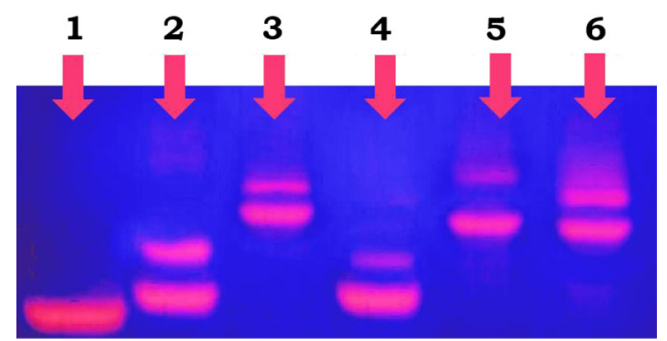

Fig. 6 Changes in the agarose gel electrophoretic pattern of pBR322 DNA induced by ligand and metal complexes. Lane 1 blank DNA (control); lane $2 \mathrm{DNA}+\mathrm{EB}+\mathrm{H}_{2} \mathrm{O}_{2}$; lane $3 \mathrm{DNA}+$ complex $2+$ $\mathrm{H}_{2} \mathrm{O}_{2}$; lane $4 \mathrm{DNA}+$ complex $1+\mathrm{H}_{2} \mathrm{O}_{2}$; lane $5 \mathrm{DNA}+$ complex $3+$ $\mathrm{H}_{2} \mathrm{O}_{2}$; lane $6 \mathrm{DNA}+\mathrm{L}+\mathrm{H}_{2} \mathrm{O}_{2}$

the DNA base pairs leads to an augmentation in both the positive and negative band.

\section{Viscosity measurement}

Viscosity of DNA is sensitive to its length. Intercalating agents are expected to elongate the double helix to accommodate the ligands in between the base, leading to an increase in the viscosity of DNA [37]. As a confirmation of the above statement, the influence of newly synthesized ligand and complexes $1-3$ on the relative viscosity of CT-DNA was performed (Fig. 5). The results revealed that the presence of the complexes had a marked effect on the viscosity of the CTDNA solution, which is similar to that of the proven DNA intercalating agent ethidium bromide. The results suggested that the ligand and the complexes intercalate between the base pairs of DNA. Notably, complex 2 possess higher viscosity of
CT-DNA than complexes 1 and 3 , which is reinforcing our interpretation based on binding studies.

\section{Electrophoresis studies}

The ability of the complex to cleave supercoiled DNA was determined by agarose gel electrophoresis. When circular plasmid DNA in the presence of an inorganic molecule is subjected to electrophoresis, relatively fast migration will be observed for the undamaged supercoiled form (form I). If scission occurs on one strand, the super coil will relax to produce a slower moving open circular form (form II). If both the strands are cleaved, a linear form (form III) that migrates in between forms I and II will be generated [38]. The progress of the pBR322 DNA cleavage reaction with increasing concentrations of each complex in the presence of $\mathrm{H}_{2} \mathrm{O}_{2}$ is given in Fig. 6. From the results shown in Fig. 6, it can be deduced that all the complexes exhibit potential nuclease activity under physiological conditions ( $\mathrm{pH} \mathrm{7.2)}$ at room temperature in the presence of hydrogen peroxide $\left(\mathrm{H}_{2} \mathrm{O}_{2}\right)$. This damage may be attributed to the formation of hydroxyl free radicals. These $\mathrm{OH}$ radicals participate in the oxidation of the deoxyribose moiety, followed by hydrolytic cleavage of the sugar phosphate backbone. Under identical experimental conditions, DNA cleavage competences of the complexes follow the trend $1>3>1>L$. The perceived difference in DNA nicking efficiency can be ascribed to the different binding affinity and intercalative strength of the complexes to DNA [39].
Table 3 Antioxidant activity of ligand $(L)$ and complexes $1-3$ (DPPH assay)

\begin{tabular}{clllll}
\hline $\begin{array}{c}\text { Concentration } \\
(\mu \mathrm{g} / \mathrm{mL})\end{array}$ & \multicolumn{6}{l}{$\%$ inhibition ${ }^{\mathrm{a}}$} & & & \\
\cline { 2 - 6 } & $\mathrm{AA}$ & $\mathrm{L}$ & {$\left[\mathrm{CoL}^{1} \mathrm{~L}^{2} \mathrm{Cl}_{2}\right]$} & $\begin{array}{l}{\left[\mathrm{CuL}^{1} \mathrm{~L}^{2} \mathrm{Cl}_{2}\right]} \\
( \pm 0.1-0.3)\end{array}$ & $\begin{array}{l}{\left[\mathrm{ZnL}^{1} \mathrm{~L}^{2} \mathrm{Cl}_{2}\right]} \\
( \pm 0.08-0.6)\end{array}$ \\
\hline 0 & 0 & 0 & 0 & 0 & 0 \\
20 & 12.4 & 0.9 & 3.1 & 11.4 & 4.1 \\
40 & 24.9 & 1.8 & 5.3 & 15.8 & 7.4 \\
60 & 30.4 & 2.2 & 8.4 & 19.7 & 11.4 \\
80 & 37.4 & 3.4 & 11.2 & 24.8 & 16.2 \\
100 & 40.1 & 6.3 & 14.3 & 30.1 & 22.1 \\
120 & 46.3 & 8.4 & 18.1 & 36.4 & 27.4 \\
140 & 55.8 & 10.4 & 21.4 & 43.8 & 31.7 \\
160 & 62.4 & 13.5 & 25.1 & 49.7 & 36.8 \\
180 & 72.5 & 17.8 & 29.6 & 54.7 & 41.6 \\
200 & 78.4 & 20.7 & 33.4 & 61.4 & 47.5 \\
220 & 84.5 & 24.4 & 37.3 & 66.4 & 52.4 \\
240 & 92.4 & 27.2 & 42.7 & 73.6 & 57.2 \\
260 & 95.8 & 31 & 48.1 & 78.4 & 62.1 \\
\hline
\end{tabular}

${ }^{\text {a }}$ Value represent the mean \pm standard error mean $(\mathrm{SEM})$ of three experiments 
Table 4 Minimum inhibitory concentration of the synthesized compounds against the growth of bacteria $(\mu \mathrm{g} / \mathrm{mL})$

\begin{tabular}{cccccc}
\hline S. no. & Compound & \multicolumn{4}{l}{ Minimum inhibitory concentration $(\mathrm{MIC})\left(10^{4} \mu \mathrm{M}\right)$} \\
\cline { 3 - 6 } & & $\begin{array}{l}\text { Bacillus } \\
\text { subtilis }\end{array}$ & $\begin{array}{l}\text { Staphylococcus } \\
\text { aureus }\end{array}$ & $\begin{array}{l}\text { Escherichia } \\
\text { coli }\end{array}$ & $\begin{array}{l}\text { Pseudomonas } \\
\text { aeruginosa }\end{array}$ \\
\hline 4 & Ligand (L) & $11.5 \pm 0.56$ & $8.5 \pm 1.02$ & $12.6 \pm 1.03$ & $10.4 \pm 0.61$ \\
3 & {$\left[\mathrm{CoL}^{1} \mathrm{~L}^{2} \mathrm{Cl}_{2}\right]$} & $11.7 \pm 0.77$ & $13.7 \pm 0.6$ & $17.4 \pm 0.09$ & $9.4 \pm 1.33$ \\
2 & {$\left[\mathrm{CuL}^{1} \mathrm{~L}^{2} \mathrm{Cl}_{2}\right]$} & $15.2 \pm 1.21$ & $18.4 \pm 0.07$ & $16.9 \pm 0.35$ & $15.7 \pm 0.82$ \\
5 & {$\left[\mathrm{ZnL}^{1} \mathrm{~L}^{2} \mathrm{Cl}_{2}\right]$} & $12.9 \pm 0.05$ & $15.7 \pm 1.12$ & $13.3 \pm 0.74$ & $11.2 \pm 1.57$ \\
6 & $\mathrm{Ciprofloxacin}$ & $14.8 \pm 0.97$ & $19.6 \pm 0.48$ & $18.5 \pm 1.15$ & $16.2 \pm 1.38$ \\
\hline
\end{tabular}

\section{Radical savaging activity}

DPPH is a stable free radical. Because of the odd electron, DPPH shows a strong absorption band at $517 \mathrm{~nm}$ in the visible spectrum. When DPPH accepts an electron donated by an antioxidant compound, the DPPH is decolorized which can be quantitatively measured by changes in absorbance [40]. The results of free radical scavenging activity of newly synthesized ligand and complexes $1-3$ at different concentrations are shown in Table 3. Inhibition values of the complexes were compared with vitamin $\mathrm{C}$, used as standard. It is evident from results that free radical scavenging activity of complexes was comparable and less than that of the standard (vitamin C). This could be attributed to the coordination of metal after complexation of the system, increasing its capacity to stabilize unpaired electrons and thereby, to scavenge free radicals.

The $\mathrm{IC}_{50}$ value, i.e., the concentration of the complexes required to reduce the initial absorption by $50 \%$, was determined. Among the complexes examined, complex 2 showed a strong interactive ability with $\mathrm{DPPH}$ with the $\mathrm{IC}_{50}$ value of $159 \mu \mathrm{g} / \mathrm{mL}$, while the ligand $(L)$, complex 1 and 3 showed moderate activity with the $\mathrm{IC}_{50}$ values of 252,230 , and $211 \mu \mathrm{g} / \mathrm{mL}$, respectively. Thus, the information obtained from the current work would be beneficial to develop new potential antioxidants and therapeutic agents for some diseases.

\section{Antimicrobial activity}

For the past few decades, designing of complexes that can act as target to constrain the pathogenic gene from replication and transcription has drawn much the interest of researchers. The newly prepared ligand and complexes were screened for their in vitro antibacterial and antifungal activities against the selected bacterial and fungal strains. Inhibition zones were measured and compared with the controls (Tables 4 and 5). Minimum inhibitory concentrations (MICs) were determined by the broth micro dilution method. It is evident from the results that all the complexes displayed varying inhibitory effects on the growth of bacterial and fungal strains. Among the metal complexes studied, complex 2 showed highest antibacterial and antifungal activity, nearly equivalent to standard drugs ciprofloxacin and nystatin.

It is also to be noted that the complexes display more activity than the ligand under alike experimental conditions. This can be explained by the help of Overtone's concept, which explains that the activity is due to the enhanced penetration of complexes into the lipid membranes. Also, on chelation, polarity of the metal ion is reduced to a greater extent due to the overlapping of the ligand orbital and partial sharing of the positive charge of the metal ion with donor groups [41].

\section{Molecular docking studies}

Molecular docking is a key tool in computer-aided drug design, which aims to accomplish an optimized conformation for both the target (DNA/protein) and drug with relative orientation between them and thereby minimizing the free energy of the overall system [42]. In order to validate the observed DNA binding ability of the synthesized complexes, molecular docking studies of the mixed ligand complexes with BDNA (PDB ID: 1BNA) were performed to understand the putative binding site. The minimum energy
Table 5 Minimum inhibitory concentration of the synthesized compounds against the growth of fungi $(\mu \mathrm{g} / \mathrm{mL})$

\begin{tabular}{cllccl}
\hline S. no. & Compound & \multicolumn{4}{l}{ Minimum inhibitory concentration $(\mathrm{MIC})\left(10^{4} \mu \mathrm{M}\right)$} \\
\cline { 3 - 6 } & & Candida parapsilosis & Candida tropicalis & Candida kefyr & Candida albicans \\
\hline 1 & Ligand (L) & $10.2 \pm 2.03$ & $9.6 \pm 0.07$ & $11.7 \pm 1.17$ & $12.3 \pm 1.05$ \\
2 & {$\left[\mathrm{CoL}^{1} \mathrm{~L}^{2} \mathrm{Cl}_{2}\right]$} & $10.8 \pm 0.99$ & $13.6 \pm 1.31$ & $14.5 \pm 0.82$ & $12.6 \pm 2.03$ \\
3 & {$\left[\mathrm{CuL}^{1} \mathrm{~L}^{2} \mathrm{Cl}_{2}\right]$} & $16.4 \pm 0.06$ & $15.8 \pm 1.93$ & $18.9 \pm 0.08$ & $16.5 \pm 0.67$ \\
5 & {$\left[\mathrm{ZnL}^{1} \mathrm{~L}^{2} \mathrm{Cl}_{2}\right]$} & $15.2 \pm 1.45$ & $14.4 \pm 2.44$ & $15.7 \pm 1.26$ & $11.2 \pm 1.11$ \\
6 & Nystatin & $17.3 \pm 1.04$ & $16.3 \pm 2.07$ & $19.2 \pm 0.05$ & $18.1 \pm 0.78$ \\
\hline
\end{tabular}


docked pose of the ligand and complex $1-3$ is given in Fig. 7. It is evident from Fig. 7 that the metal complexes binds to DNA via intercalation involving the outside edge stacking interactions with the oxygen atom of the phosphate backbone of DNA [43]. On analyzing the docked structures, it is obvious that the metal complexes fit well into the A-T-rich region of the target DNA. The relative binding energies obtained were found to be $-3.12,-3.25,-4.21$, and $-3.67 \mathrm{kcal} /$ mol for ligand $(L)$ and complexes $1-3$, respectively. When the relative binding energy is more negative, the binding of the complex with DNA is greater [44]. The binding affinity of the present complexes follows the order, complex 2$>$ complex $3>$ complex $1>L$. The present docking study shows that the complexes possess more affinity for DNA than the ligand. Thus, it is concluded that there is a mutual match between the in vitro and in silico studies.

\section{Conclusion}

This work describes the synthesis and characterization of mixed ligand $\mathrm{Co}(\mathrm{II}), \mathrm{Cu}(\mathrm{II})$, and $\mathrm{Zn}(\mathrm{II})$ complexes involving 1,4-naphthoquinone, L- histidine, and 1,10-phenanthroline ligands. Preliminary in vitro DNA binding abilities of the ligand and the complexes were explored by absorption spectroscopy, cyclic voltammetry, viscosity, and CD measurements. The corroborative results of these experiments validate
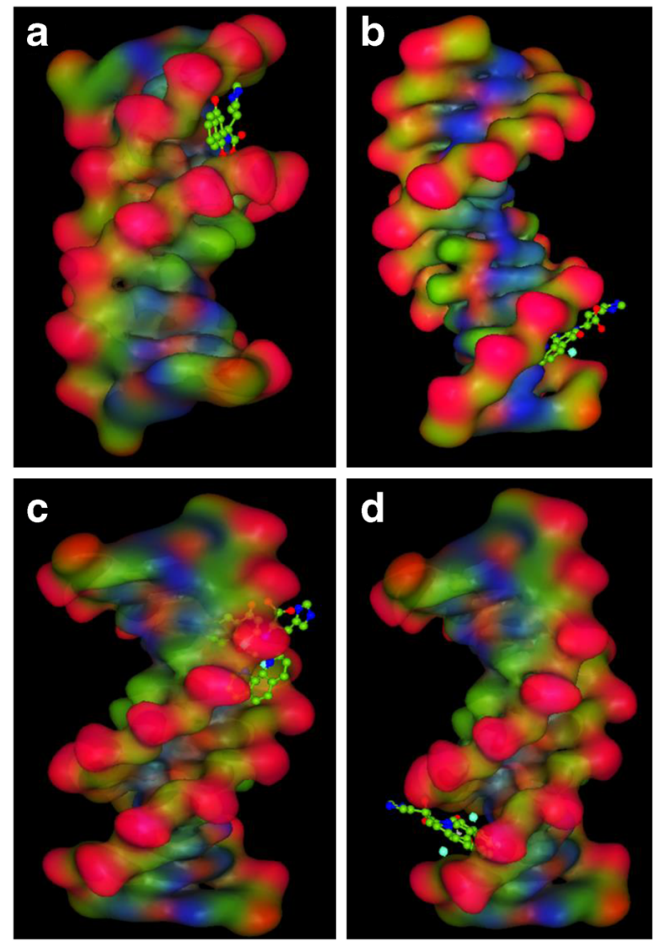

Fig. 7 Molecular docked model of the ligand and complexes $1-3$ with DNA dodecamer duplex of sequence d(CGCGAATTCGCG) 2 (PDB ID: 1BNA) that all complexes bind to CT-DNA by intercalation. It appears from the DNA cleavage studies that the ligand and the complexes cleave supercoiled DNA in the presence of $\mathrm{H}_{2} \mathrm{O}_{2}$. All the complexes were screened for their in vitro antimicrobial activity and unveiled varying degrees of inhibitory effects on the selected pathogens. In addition, the antioxidant activity of the complexes was also investigated. Among the three complexes, complex 2 showed a strong interactive ability with DPPH. Molecular docking studies were carried out to authenticate the spectroscopic studies which revealed that the complexes bind to DNA via intercalation. These results show that these complexes have many promising applications, which may lead to new and effective nucleic acid molecular probes and new therapeutic agents for diseases on the molecular level.

Acknowledgement The authors sincerely thank the UGC, New Delhi, India, for the financial support under major research project (UGC File No. 42-238/2013 (SR)), the Principal and management of Bishop Heber College, Tiruchirappalli, Tamilnadu, India, for their constant encouragement and for providing the necessary facilities. The authors also gratefully acknowledge SAIF, IIT, Chennai, and CRDI, Lucknow, for providing the analytical instrument facility.

\section{References}

1. Maurya RC, Pandey A, Verma R (2002) Synthesis, magnetic and spectral studies of some new mixed-ligand nitrosyl complexes of chromium (I). Indian J Chem A 41:339-341

2. Sarkar S, Maurya RC, Chaurasia SC (1976) BIS (ACETYLACETONATO) NITROSYL CR (I). Indian J Chem A J 14:285

3. Chandra S, Gupta LK (2004) EPR, IR and electronic spectral studies on $\mathrm{Mn}$ (II), $\mathrm{Co}$ (II), $\mathrm{Ni}$ (II) and $\mathrm{Cu}$ (II) complexes with a new 22membered azamacrocyclic [N 4] ligand. Spectrochim Acta A 60: $1751-1761$

4. O'brien PJ (1991) Molecular mechanisms of quinone cytotoxicity. Chem-Biol Interact 80:1-41

5. Zuman P (1967) Substituent effects in organic polarography. Plenum Press, New York

6. Vassilev K, Dimitrova M, Turmanova S, Milina R (2013) Catalytic activity of histidinemetal complexes in oxidation reactions. Syn React Inorg Met 43:243-249

7. Stryer L (1988) Biochemistry. WH Freeman and Company, New York

8. Mesu JG, Visser T, Soulimani F, Weckhuysen BM (2005) Infrared and Raman spectroscopic study of $\mathrm{pH}$-induced structural changes of L-histidine in aqueous environment. Vib Spectrosc 39(1):114 125

9. Nagaoka H, Kishi Y (1981) Further synthetic studies on rifamycin S. Tetrahedron 37:3873-3888

10. Sharmaa U, Katocha D, Soodb S, Kumar N, Singha B, Thakurb A, Gulatib A (2013) Synthesis, antibacterial and antifungal activity of 2-amino-1, 4-naphthoquinones using silicasupported perchloric acid (HClO 4-SiO 2) as a mild, recyclable and highly efficient heterogeneous catalyst. Indian J Chem 52:1431-1440

11. Lancini G (1977) Structure-Activity Relationship among the Semisynthetic Antibiotics. Academic Press, New York 
12. Lanz T, Tropf S, Marner FJ, Schröder J, Schröder G (1991) The role of cysteines in polyketide synthases. Site-directed mutagenesis of resveratrol and chalcone synthases, two key enzymes in different plant-specific pathways. J Biol Chem 266:9971-9976

13. Summers LA (1978) The phenanthrolines. Adv Heterocycl Chem 22:1-69

14. Sammes PG, Yahioglu G (1994) 1, 10-Phenanthroline: a versatile ligand. Chem Soc Rev 23:327-334

15. Luman CR, Castellano FN (2004) In: McCleverty JA, Meyer TJ (eds) Lever ABP Comprehensive Coordination Chemistry, vol 1. Elsevier, Oxford, UK

16. Zhao G, Lin H (2005) Metal complexes with aromatic N-containing ligands as potential agents in cancer treatment. Curr Med Chem 5: 137-147

17. Dhayabaran VV, Prakash TD (2016) Influence of Amino AcidNucleobase Hybrid Ligand in Binding and Biological Activity of Co (II) and Zn (II) Complexes. J Fluoresc 26:1825-1837

18. Lakshmi B, Avaji PG, Shivananda KN, Nagella P, Manohar SH, Mahendra KN (2011) Synthesis, spectral characterization and in vitro microbiological evaluation of novel glyoxal, biacetyl and benzil bis-hydrazone macrocyclic Schiff bases and their Co (II), $\mathrm{Ni}$ (II) and $\mathrm{Cu}$ (II) complexes. Polyhedron 30:1507-1515

19. Dolaz M, McKee V, Urus S, Demir N, Sabik AE, Gölcü A, Tümer M (2010) Synthesis, structural characterization, catalytic, thermal and electrochemical investigations of bidentate Schiff base ligand and its metal complexes. Spectrochim Acta A 76:174-181

20. Chohan ZH, Arif M, Sarfraz M (2007) Metal-based antibacterial and antifungal amino acid derived Schiff bases: their synthesis, characterization and in vitro biological activity. Appl Organomet Chem 21:294-302

21. Awad DJ, Conrad F, Koch A, Schilde U, Pöppl A, Strauch P (2010) 1, 10-Phenanthroline-dithiolate mixed ligand transition metal complexes. Synthesis, characterization and EPR spectroscopy. Inorg Chim Acta 363:1488-1494

22. Anacona JR, Marquez VE (2008) Synthesis of transition metal complexes containing a Schiff base ligand derived from 1, 10phenanthroline-2, 9-dicarboxaldehyde and 2-aminobenzenethiol. Transit Metal Chem 33:579-583

23. Fayad NK, Al-Noor TH, Mahmood AA, Malih IK (2013) Synthesis, Characterization, and Antibacterial Studies of Mn (II), Fe (II), Co (II), Ni (II), Cu (II) and Cd (II) Mixed-Ligand Complexes Containing Amino Acid (L-Valine) And (1, 10phenanthroline). Synthesis 3(5).

24. Raman N, Mahalakshmi R, Arun T, Packianathan S, Rajkumar R (2014) Metal based pharmacologically active complexes of $\mathrm{Cu}$ (II), $\mathrm{Ni}$ (II) and Zn (II): synthesis, spectral, XRD, antimicrobial screening, DNA interaction and cleavage investigation. J Photoch Photobio B 138:211-222

25. Speier G, Csihony J, Whalen AM, Pierpont CG (1996) Studies on aerobic reactions of ammonia/3, 5-Di-tert-butylcatechol Schiff-base condensation products with copper, copper (I), and copper (II). Strong copper (II)- radical ferromagnetic exchange and observations on a unique N- N coupling reaction. Inorg Chem 35:35193524

26. Hathaway B, Billing DE (1970) The electronic properties and stereochemistry of mononuclear complexes of the copper (II) ion. Coord Chem Rev 5:143-207

27. Facchin G, Kremer E, Barrio DA, Etcheverry SB, Costa-Filho AJ, Torre MH (2009) Interaction of Cu-dipeptide complexes with Calf Thymus DNA and antiproliferative activity of [Cu (ala-phe)] in osteosarcoma-derived cells. Polyhedron 28:2329-2334
28. Mandal S, Rout AK, Ghosh A, Pilet G, Bandyopadhyay D (2009) Synthesis, structure and antibacterial activity of manganese (III) complexes of a Schiff base derived from furfurylamine. Polyhedron 28:3858-3862

29. Tan L, Shen J, Liu J, Zeng L, Jin L, Weng C (2012) Spectral characteristics, DNAbinding and cytotoxicity of two functional $\mathrm{Ru}$ (II) mixed-ligand complexes. Dalton Trans 41:4575-4587

30. Wolfe A, Shimer GH Jr, Meehan T (1987) Polycyclic aromatic hydrocarbons physically intercalate into duplex regions of denatured DNA. Biochemistry 26:6392-6396

31. LePecq JB, Paoletti C (1967) A fluorescent complex between ethidium bromide and nucleic acids: physical — chemical characterization. J Mol Biol 27:87-106

32. Arjmand F, Jamsheera A, Mohapatra DK (2013) Synthesis, characterization and in vitro DNA binding and cleavage studies of $\mathrm{Cu}$ (II)/ Zn (II) dipeptide complexes. J Photoch Photobio B 121:75-85

33. Song Y, Yang P, Yang M, Kang J, Qin S, Lü B, Wang L (2003) Spectroscopic and voltammetric studies of the cobalt (II) complex of Morin bound to calf thymus DNA. Transit Metal Chem 28:712716

34. Grover N, Gupta N, Singh P, Thorp HH (1992) Studies of electrocatalytic DNA cleavage by oxorutheinum (IV). X-ray crystal structure of [Ru (tpy)(tmen) $\mathrm{OH} 2](\mathrm{CIO} 4) 2$ (tmen). Inorg Chem 31: 2014-2020

35. Pasternack RF (2003) Circular dichroism and the interactions of water soluble porphyrins with DNA - a minireview. Chirality 15 : 329-332

36. Zhang S, Zhu Y, Tu C, Wei H, Yang Z, Lin L, Ding J, Zhang J, Guo $\mathrm{Z}$ (2004) A novel cytotoxic ternary copper (II) complex of 1, 10phenanthroline and L-threonine with DNA nuclease activity. J Inorg Biochem 98:2099-2106

37. Satyanarayana S, Dabrowiak JC, Chaires JB (1992) Neither deltanor lambda-tris (phenanthroline) ruthenium (II) binds to DNA by classical intercalation. Biochemistry 31:9319-9324

38. Barton JK, Danishefsky A, Goldberg J (1984) Tris (phenanthroline) ruthenium (II): stereoselectivity in binding to DNA. J Am Chem Soc 106:2172-2176

39. Fu XB, Zhang JJ, Liu DD, Gan Q, Gao HW, Mao ZW, Le XY (2015) $\mathrm{Cu}$ (II)-dipeptide complexes of 2-(4'-thiazolyl) benzimidazole: Synthesis, DNA oxidative damage, antioxidant and in vitro antitumor activity. J Inorg Biochem 143:77-87

40. Kavitha P, Saritha M, Reddy KL (2013) Synthesis, structural characterization, fluorescence, antimicrobial, antioxidant and DNA cleavage studies of $\mathrm{Cu}$ (II) complexes of formyl chromone Schiff bases. Spectrochim Acta A 102:159-168

41. Anjaneyulu Y, Rao RP (1986) Preparation, characterization and antimicrobial activity studies on some ternary complexes of $\mathrm{Cu}$ (II) with acetylacetone and various salicylic acids. Syn React Inorg Met 16:257-272

42. Beteringhe A, Racuciu C, Balan C, Stoican E, Patron L (2013) Molecular Docking Studies Involving Transitional Metal Complexes (Zn (II), Co (II), Cu (II), Fe (II), Ni (II) with Cholic Acid (AC)) as Ligand against Aurora A Kinase. Adv Mater Res 787:236-240

43. Gao YG, Wang AH (1991) Influence of aglycone modifications on the binding of anthracycline drugs to DNA: the molecular structure of idarubicin and 4-O-demethyl-11-deoxydoxorubicin complexed to d (CGATCG). Anticancer Drug Des 6:137-149

44. Arun T, Packianathan S, Malarvizhi M, Antony R, Raman N (2015) Bio-relevant complexes of novel N 2 O 2 type heterocyclic ligand: synthesis, structural elucidation, biological evaluation and docking studies. J Photoch Photobio B 149:93-102 